\title{
Implementation of Participatory Design Approach in Jakarta Community Center (RPTRA)
}

\author{
Eka Permanasari, PhD $^{1}$ \\ ${ }^{1}$ Faculty of Technology and Design, Universitas Pembangunan Jaya, Tangerang, Indonesia \\ 1eka.permanasari@upj.ac.id
}

\begin{abstract}
Jakarta is the city full of symbolism where most of government projects are manifestation of authority's agenda. Using the top down approach, political insinuation in architecture and built forms are common practices in many countries to convey national identity. In 2015, the Governor of Jakarta launched the Jakarta community center called RPTRA (Ruang Publik Terpadu Ramah Anak) as a new direction for making public spaces. The 6 pilot projects located in 6 municipalities of Jakarta work as representatives of the new Jakarta. These projects not only symbolize the new face of Jakarta, but also portray it as a happy city. While most of policy in making public places uses top down approach, these new community centres proposed a different perspective. Grounded heavily on bottom up and participatory design approaches, the Governor of Jakarta deployed a team to initiate the program and included public participation in every step of its development. Yet, to what extent these community centers have enabled people to actively engage in the process of participative design? Through observation, interview and a series of group focused interviews, this article looks at the ways in which public space became an arena where government's agenda and people's participation meet. The participative design process has a long way to go to be ideal, but these pilot projects have put Jakarta as a new symbol of a democratic city. For its many layers of history, Jakarta collects, channels and diminishes people's dream, imagination and hopes.
\end{abstract}

Keywords: architecture, participative design, public space

\section{INTRODUCTION}

The city should be an object of analysis, as it is a "theatre of human events" [1]. The city should not be seen as a representation per se, but rather as a collection of events and feeling. For every event, it contains the memory of the past and potential memory of the future. The city is a locus where possibilities of events can be accommodated and constituted. The question is how if a memory of a city connects it to a bad memory? Some cities are well known as unfriendly or dysfunction while some is portrayed as livable. The design of the city should put happiness at stake, it is impossible to separate the life and design of the city [2]. While architects and urban planners design the city based on utopian thoughts and formulate the way in which people interact within the built form, Lefebvre argues that the way the space is used is indeed the privilege of space users [3].

Events and activities in public space then became some indicators of how happy a city can be. Yet, existence of public space cannot be separated from the intention of authority. As 
Lawrence Vale argues that architecture can symbolize and legitimate power of a specific regime [4]. In this case, public space might embody the authority's intention [5]. Therefore, it is interesting to analyze the way public space is design and how it negotiates the needs of public and the government. As public space is designed for public, quite often it only represents the needs of government. However, recently there are some approaches to shift from top down approach to user-centered design process, namely participative design approach. The process specifically looks at the ways in which fulfilling the needs of the users [6]. As opposed to the needs of fulfilling the authority's agenda, participatory design approach focuses on what should be done for the best of the users [7]. The main problem is, how to mediate people's need and incorporate it into design. The process requires dialogue between architect, users and social researcher. However, this process is rather tricky and often blurs the intention between the users, social researcher, the architect and the government. As planning and design is a wicked problem [8], nobody agrees about what the problem is exactly. In order to understand the problem, we need to dig out exhaustive possible solutions ahead. The process of design participation needs to distinguish the "demand of the clients and the desires of users" [9]. While most of the architects are hired by the clients and often followed the client's agenda, the general public are often excluded in the process of architectural production. In fact, the production of public spaces has been characterized by the capitalist mode of production, privatization, or overly protection over the daily uses [10]. The idea where everyone has the same right to the city is often being politicized. Architects and urban planners need to accommodate public interests in making public space accessible for everyone [11].

Jakarta is the city with multiple layers of history. Under Sukarno, Jakarta displayed its identity through constellation of monuments and public places in Jakarta [12]. Under the Suharto era, Jakarta portrayed the spectacle of economic growth. The revival of nationalism through revitalization project in the heart of Jakarta was highlighted as the success of Suharto economic reform [13]. After the fall of Suharto, the image of Jakarta was pretty much decided by its Governor. Sutiyoso for instance, revived the image of Jakarta through renovation of Sukarno's monuments and public places. Under Fauzi Bowo, Jakarta was reoriented as a new postcolonial city through the waterfront city masterplan, named as Giant Sea Wall [14].

Inspired by the TV advertisement of Termorex, late governor Ahok wanted its citizen to care for one another. In particular, Ahok wanted the neighbourhood leader (RT) and district leader (Lurah) to become the first person to be contacted when there was an emergency situation. For Ahok, the neighborhood leader played a major fole in the society. Therefore, his manoeuvre was to build a community centre where people can congregate, have activity, see and to be seen [15]. His idea was supported by his former wife, Veronika Ahok who shared the same perspective. Veronika together with Badan Pemberdayaan Masyarakat, Perempuan dan Keluarga Berencana (Community empowerment, women and family planning Department) then asked the government's counterpart (in this case PT Pembangunan Jaya) to implement the idea. PT Pembangunan Jaya appointed PT Arkonin, PT Jakon and Universitas Pembangunan Jaya to come up with the concept. As the representative of Universitas Pembangunan Jaya, I worked with Achmad Noerzaman as the architect head from PT Arkonin and Sutopo Kristanto as the chief developer from PT Jaya Konstruksi to follow up the concept. Although the initial idea was from the government, I further developed the concept and suggested to include public participation. This idea was welcomed. Veronika agreed and invited Imam Prasodjo as the social researcher to join the group. Public participation in every step of the process of building RPTRA was mandatory and was applied on the 6 pilot projects located in the 6 municipalities 
of Jakarta (Gandaria Selatan, Kembangan, Cililitan, Sungai Bambu, Cideng and Untung Java Island).

To understand the level of participation, we need to investigate the process of involving citizen in the five steps of development based on the Eight Rungs on a Ladder of Citizen Participation proposed by Arnstein. The first two rungs indicate the non-participation level where government policy is only to educate and cure participants. Rung three and four (informing and consultation) show the degrees of tokenism, which allows citizen to speak but they lack the power to ensure the opinion will be carried through. Rung five (Placation) allows citizen to advise the government yet the decision lays in the power holder only. The highest degree of citizen participation lays at the level of Degrees of citizen power. Here, rung six (partnership) allows citizen to negotiate and engage in trade-offs with the government. The two highest rungs are the delegated power and citizen control, which allow citizen to have majority decision-making and full managerial power [16] As much as Arnstein describes for the level of participation, critics over this idea shows that participants' own reason in engaging the decision-making process does not always align with this classification [17]. In fact, Choguill's (1996) argument in redefining Arnstein ladder states that where there is no government support and the citizen is neglected by the government, public seems to take control and have self-management. For Choguill, this represents the bottom of Arnstein's ladder [18].

This paper investigates the production of public places by implementing participative design approach. It analyses to what extent participative design method has enabled people to be involved in the process of designing, building and administering the public space? For this project, I positioned myself as part of the architect team and social researcher which enable dialogue between the government and the community.

\section{METHOD}

This research uses the qualitative research methodology to uncover the participative design process, the potential actors, problems and solution in negotiating the space. Zeisel (2006) has outlined that observing environmental behavior deals with the ability to systematically watch how people use the space, interact with other people and environment. By observing the surrounding, it can determine the potential actors, activities and use of places in everyday life [19]. The method is used to uncover the use of public spaces prior to the development of the community centre, certain activities that is potential to be included in the design and potential actors that are considered as active and influential for building public engagement [20].

For the purpose of this research, interview was conducted to gather information on how people define a concrete situation, how important it is, what they will do and what they feel. Using the semi structured and open-ended question, interview was conducted towards potential actors and representative identified during the observation process to uncover both factual and meaning level [21]. Interview was conducted in informal situation by having conversation with the potential actors to uncover their perspective on issues related to the activities and their hopes for the future public place development.

Group focused Interview is useful to identify a series of definition of a situation that is currently faced, to search for a particular opinion and consensus [22]. The advantage of this group focused interview is when a fact presented by one participant incites others to express their opinions and feelings. The group focused interview was used to involve the community in the process of participative community center. The observation, interview and group 
focused interviews were conducted within 6 months parallel on the 6 locations since December 2014-May 2015.

\section{RESULT AND DISCUSSION}

Unlike most of the government project, which concentrate on the public participation at the degrees of Tokenism [23], RPTRA project was aimed to place citizen as the government partner to achieve the citizen power. The participatory design approach involving the architect, the social researcher and the community was conducted at the 6 pilot projects.

\subsection{Observation and interview Process}

The first step in observation was to identify potential key persons as representatives from the society to be included in the group focused discussion. Observation was conducted through walking and sampling interview to certain people around the proposed community center area. The observation occurred within the radius of 1 kilometer around the area. Through observation and short interviews, the social researcher team categorized those who are vocal, fully respected by the society, and represent different age clusters in the group. The team identified potential threats, conflicts or possible resistance from the group. The purpose of observing and interviewing certain potential actors was to map the existing activities, facilities and person in charged in the society.

In Cideng for instance, different groups have different views regarding the government plan on building the community center. Some believed that the new community center would dismiss the existing no-registered early education center in the area, while others had their high hopes for the new community center would include the existing. However, some also considered that public space was highly needed to provide a space for interaction in a safe environment. In Cililitan, right from the start people were suspicious about the project. Before I could identify the key person, a group of people claimed themselves as representatives of Cililitan youth community of Gang Buluh. They confronted and stopped me from identifying problems and potential activities. The process of negotiating with the locals took several stages. Distrust and being suspicious postponed the project. As the result, the architect and social researcher had to closely engage with the Cililitan community. As a matter of fact, after an interview it was found that the Cililitan youth community has been in opposition to the local government in implementing policies. This has affected the process of including them in the participative design process.

\subsection{Group Focus Interview in making the design concept for the community center}

Following the observation and interview, potential activities and potential key persons who could take charge and influence the community were identified. During the Group Focused interview, I invited certain key persons to have deeper understanding about their interpretation and future dreams about the community center. Here, the architect and social researcher were hands in hands in nurturing community's participation, especially in developing design concept for the community center. Based on the initial design from the architect, I held the group focused interview to provide feedback for the architects. This process allowed community to participate in designing the community centre based on the needs and hopes. For instance, in Cideng the architect team presented the master plan and architectural drawing as their first response to the needs of the community. On the master plan, the architect allocated the hall for community gathering, library for kids, and early education centre in the main building. Meanwhile, the existing local neighborhood secretariat was opt out (Figure 1) 

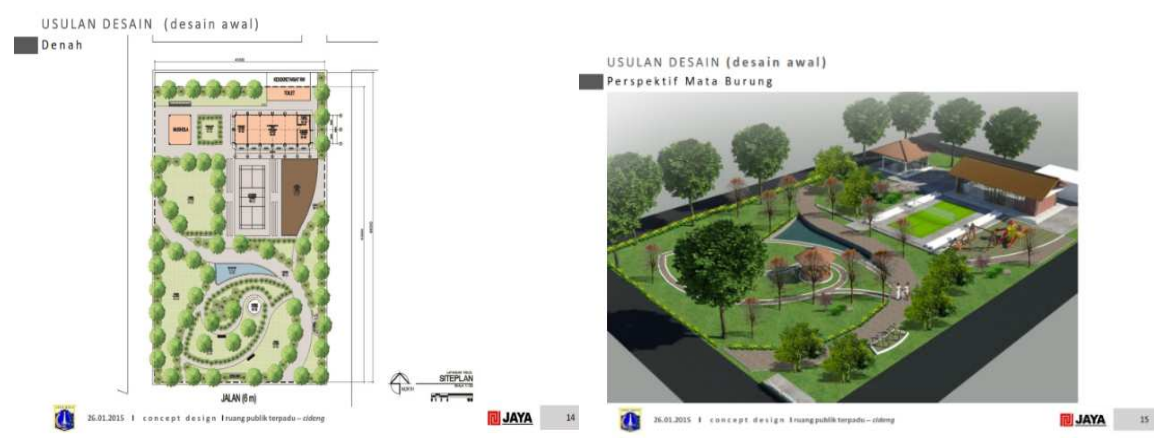

Figure 1: Site plan RPTRA in Cideng

Source: Author

The group focused interview was held aiming to get a feedback from the representatives. Participants were divided based on age category (elderly, parents, teenagers, and children) to get complete aspiration from different clusters of community. The groups discussed the activities that should be regularly run in the community center which affect the design proposed by the architect. Based on the result, the team could gather information on community's expectation, dream and opinion on the proposed design.

While the Group Focused interview in Cideng was relatively effective, the same process faced difficulties in Cililitan. The Family Welfare Organization was in conflict with the local youth. As the Family welfare organization has a strong connection with the government, the youth community of Gang Buluh had interpretation that the community center was just another government led project without considering local aspiration.

Meanwhile, Kembangan, Gandaria Selatan, Sungai Bambu and Untung Java area had a smoother process than the former two. The interaction between the government, the Family Welfare organization and the community were strong [12]. This accelerates the process of participative design as the community is so adaptive and welcome to the proposed design.

The Group Focused interview on the concept design on these 6 locations is to do participative design and receive initial feedback from the community. Here the social researcher and the architect worked together to reach the negotiated space approved by all parties. Once the group agreed on the consensus, the architect revised the design before presenting it again in front of the community on the next step.

\subsection{Group Focused Interview in finalizing design}

Based on the initial feedback, I held another round of Group Focused Interview to receive final feedback from the community about the revised design. At this stage, negotiation on the organization and the use of space will be finalized. The role of social researcher is to negotiate the differences between the ideal and the limited soace. Based on the group focused interview, all parties in 4 locations agreed and signed the final design to show their commitment and accepting the negotiated space. Some differences such as activities to be included and the space allocation were mediated.

\subsection{Working together in building the community center}

Once the final design was agreed, the architect and social researcher team initiated another event to raise community engagement in building the RPTRA. The participative design approach was not only aimed during the design but also the development of the community center. On the ground-breaking day, the people surrounding the area and all the 
representatives together with the architect, social researcher, the local government and I helped the construction workers in building the community center. The representatives from different groups were invited to the event. During the process of building the community center, some representatives in Cideng did not join the event. They chose to watch the process instead of actively involved in the process. However, in Cililitan the formerly divided groups joined the event and helped the team to clean up the site. The process became a turning point and realization of the broken hope due to the difficult argument from the previous Group Focused Interview sessions.

\subsection{Group Focused Interview in planning activities, PIC and facility sharing.}

This process is the last step of participative design approach. The Group Focused interview with architect, social researcher and representatives was held to designed types of activities, schedules and persons in charge. The aim of this group focused interview was to raise community awareness, responsibility and facility sharing. The process was carefully done by observing and questioning the representatives about their community engagement. The appointed persons in charge were the local leaders consistent in joining the Group Focused Interviews and showed big interest in empowering the locals. This process allowed the new appointed leaders both from the formal organization and the informal groups to work together with the community.

All these five steps of development were carried out on the 6 pilot projects. Through the process, the community sees a way that aspiration may be channeled, and differences may be negotiated. During this process, all the differences seem to have gone away as they saw the community centre to be for the interest of all. Even though the attempt to include community in designing RPTRA, community representatives were at the tokenism higher level, the placation degree, where community can advise on how the design should be but leave the decision to government and the architect team. Community participation was at the degrees of citizen power where the government has partnership with the community in building the RPTRA. In other stage of development, community participation was at the maximum level where they decided activity schedule, person in charge and facilities sharing. During this stage, public participation is at the highest level of citizen power where citizen control takes place.

\section{CONCLUSION}

Despite all the problems faced during the process of participative design method, the process had open the eyes of both sides (the government and the community). These 6 pilot projects facilitated the community's expectation, dream and hope. Regardless some difficulties, these community centers were launched in May 2015. Considered the RPTRA to be a successful project, Ahok instructed to build 200 RPTRA located on each Jakarta district based on these 6 pilot projects. Using CSR fund from companies, Ahok built another 51 RPTRA by 2016 [24]. He continued his program and partly-launched around 123 RPTRA in 2017 including the most famous RPTRA Kalijodo designed by Yori Antar. Unfortunately, the project received massive criticism as it was built by the CSR funds instead of government budget. Ahok then made maneuver and collaborated with the Housing bureau to build the rest of ongoing projects. In 2017, Ahok was forced to quit his governance due to blasphemy case and replaced by vice governor Djarot who continued his RPTRA dream. Even though the process of participative design approach was not ideal, community had a chance to channel 
their aspiration. The new face of Jakarta is no longer through the constellation of monuments in the center, but rather by the development of hundred community centers sprang across the city. Jakarta was intended to be portrayed as a happy and child-friendly city.

\section{REFERENCES}

[1]. Rossi, A. (1986). The Architecture of the City. US: The MIT Press.

[2]. Montgomery, C. (2013). Happy City. London: Penguin Books.

[3]. Lefebvre, H. (1996). Writing on Cities. Oxford: Blackwell Publisher.

[4]. Vale, L. (1992). Architecture, Power and National Identity. London: Yale University Press.

[5]. Alsayyad, N. (. (1992). Forms of Dominance: On the Architecture and Urbanism of the Colonial Enterprise. . Avebury: Aldershot.

[6]. Sanders, Elizabeth B-N; SonicRim. (2002). From User-Centered to Partisipatory Design Approach. In J. Frascara, Design and Social Sciences: Making Connections. London And New York: taylor and Francis.

[7]. Cowen, M., \& Shenton, R. (1996). Doctrines of Development. London: Routledge.

[8]. Tritter, J., \& McCallum, A. The snakes and ladders of user involvement: Moving beyond Arnstein. Health Policy Journal, Vol 76, pp.156-168. 2006

[9]. Jones, P., Petrescu, D., \& Till, J. (2012). Architecture and Participation. London and New York: Routledge.

[10]. Kahraman, M., Pak, B., \& Scheerlinck, K. Production of Heterotopias as Public Spaces and Paradox of Political Representation: A Lefebvrian Approach. ITU AZ Journal, Vol 15 No 1, pp.135-145. 2018.

[11]. Tonnelat, S. (2010). The Sociology of urban Public Spaces. In H. Wang, M. Savy, \& G. Zhai, Territorial Evolution and Planning Solution: Experience from China and France (pp. 1-10). Paris: Atlantis Press.

[12]. Permanasari, E., Mochtar, S., \& Purisari, R. Political Representation in Urban Public Space in Jakarta Child-Friendly Public Space (Ruang Publik Terpadu Ramah Anak-RPTRA). International Journal of Built Environment and Sustainability. Vol 6, No 2, pp. 39-49. UTM, Malaysia. 2019

[13]. Permanasari, E. (2010). Constructing and Deconstructing the Nation: Sukarno's Monuments and Public Places in Jakarta. Germany: LAP Lambert Publishing.

[14]. Permanasari, E. Redefining New (Postcolonial) Jakarta through the Giant Sea Wall Project. IASTE Working Paper Series: Culture and Myth in Socio-Spatial Practice., Vol 256, pp. 32-42. 2014

[15]. Jacobs, J. (1992). The Death and Life of Great American Cities. New York: Vintage Books.

[16]. Arnstein, S. R. A Ladder of Citizen Participation. Journal of the American Planning Association, Vol 35, No 4, pp. 216-224. 1969

[17]. Tritter, J., \& McCallum, A. The snakes and ladders of user involvement: Moving beyond Arnstein. Health Policy, Vol76, pp. 156-168. 2006.

[18]. Choguill, M. B. (1996). A ladder of community participation for underdeveloped countries. Habitat International, Vol 20 No 3, pp. 431-444.

[19]. Zeisel, J. (2006). Inquiry by Design. California: Cambridge University Press.

[20]. Neuman, L. W. (2006). Social Research Methods: Qualitative and Quantitative Approaches. USA: Pearson Education.

[21]. Kvale, S. (1996). Interviews: an Introduction to Qualitative Research Intervieweing. Sage Publication.

[22]. Neuman, L. W. (2006). Social Research Methods: Qualitative and Quantitative Approaches. USA: Pearson Education.

[23]. Tjahjono, H., Bisri, M., Soemarno, \& Ganis, E. Public Participation towards the Formulation of Environment-friendly city Policy in Tulungagung. International journal of Applied Sociology, Vol 4. No 3, 74-81. 2014

[24]. Aziza, K. (2015, October 28). Bangun 57 RPTRA, Ahok Teken Kerja Sama dengan 19 Perusahaan Swasta. Kompas. 